\title{
KELAYAKAN USAHA SERTA KARAKTERISTIK KIMIA DAN MIKROBIOLOGI MANGUT LELE KALENG
}

\section{FEASIBILITY STUDY AND CHEMICAL-MICROBIOLOGICAL CHARACTERISTICS OF CANNED CATFISH}

\author{
Ervika Rahayu Novita Herawati, Agus Susanto, Asep Nurhikmat, Muhammad \\ Kurniadi \\ Balai Penelitian Teknologi Bahan Alam - Lembaga Ilmu Pengetahuan Indonesia, \\ Jalan Jogja-Wonosari km 31,5 Gading, Playen, Gunungkidul, Yogyakarta, Indonesia \\ E-mail : ervika.lipi@gmail.com
}

\begin{abstract}
Abstrak
Sebagian besar makanan tradisional di Indonesia memiliki masa simpan rendah, salah satunya mangut lele. Ikan lele yang dimasak dalam bumbu mangut ini merupakan makanan khas daerah Jawa yang banyak disukai masyarakat. Salah satu teknologi yang dapat dilakukan untuk meningkatkan masa simpan adalah dengan pengemasan menggunakan kemasan kaleng. Tahapan proses pengalengan meliputi preparasi bahan, pembuatan sayur mangut lele, pengisian dalam kaleng, penghampaan udara $\left(80^{\circ} \mathrm{C}, 10\right.$ menit), penutupan kaleng, sterilisasi $\left(121^{\circ} \mathrm{C}, 20\right.$ menit), pendinginan, dan karantina 14 hari. Analisa teknoekonomi telah dilakukan terhadap pengalengan mangut lele dengan kapasitas produksi sebesar 1000 kaleng/hari. Nilai Return of Investment (ROI) cukup tinggi, sehingga usaha produksi pengalengan mangut lele ini sangat potensial untuk dikembangkan.Proses pengalengan telah dilakukan terhadap produk mangut lele dengan nilai Fo/kecukupan panas sebesar 10,48 menit. Karakteristik kimia mangut lele kaleng meliputi kadar air 75,71\%; kadar abu 2,30\%; lemak 6,24\%; protein 12,30\%; dan karbohidrat 3,45\%. Mangut lele kaleng mengandung 119 kalori per 100 gram produk. Pengujian mikrobiologi menunjukkan produk negatif dari kandungan salmonella, staphylococcus aureus, dan clostridium. Pengujian cemaran logam telah dilakukan dan hasilnya masih dibatas aman yaitu timbal $(\mathrm{Pb})$ $<0,0007 \mathrm{mg} / \mathrm{kg}$; tembaga (Cu) $0,0718 \mathrm{mg} / \mathrm{kg}$; seng $(\mathrm{Zn}) 0,0022 \mathrm{mg} / \mathrm{kg}$; timah $(\mathrm{Sn})<0,8$ $\mathrm{mg} / \mathrm{kg}$; mercuri $(\mathrm{Hg})<0,0003 \mathrm{mg} / \mathrm{kg}$; arsen (As) 0,029 mg/kg.
\end{abstract}

Kata kunci : Karakteristik kimia, karakteristik mikrobiologi, kelayakan usaha, mangut lele kaleng

\begin{abstract}
Most traditional foods in Indonesia have a short shelf lifetime, one of which is catfish curry. Catfish curry is catfish that cooked in curry seasoning which is a typical Javanese food that many people like. One of the technologies that can increase the shelf lifetime of catfish is by packaging using cans. The canning process stage includes preparation of materials, making of catfish curry, filling in cans, exhausting at $80^{\circ} \mathrm{C}$ for 10 minutes, seaming cans, sterilizing $121^{\circ} \mathrm{C}$ for 20 minutes, cooling, and quarantine for 14 days. Techno-economy analysis has been carried out on the canning of catfish with a production capacity of 1000 cans/day. The value of Return of Investment (ROI) is quite high, so it is very potential to developed the
\end{abstract}


canning business. The canning process has been carried out on the catfish product with Fo / thermal sufficiency value of about 10.48 minutes. The chemical characteristics of canned catfish curry include water content of $75.71 \%$; ash content of $2.30 \% ; 6.24 \%$ fat; $12.30 \%$ protein; and carbohydrates 3.45\%. Canned catfish curry contains 119 calories per 100 grams of the product. The microbiological analysis shows negative content from salmonella, staphylococcus aureus, and clostridium. Analysis of metal contamination has been carried out and the results showed the safe product which contain lead $(\mathrm{Pb})<0,0007 \mathrm{mg} / \mathrm{kg}$; Copper (Cu) $0.0718 \mathrm{mg} / \mathrm{kg} ;$ zinc (Zn) $0.0022 \mathrm{mg} / \mathrm{kg}$; tin (Sn) <0.8 mg / kg; mercury (Hg) $<0,0003 \mathrm{mg} / \mathrm{kg} ;$ and arsenic (As) $0.029 \mathrm{mg} / \mathrm{kg}$.

Keywords: catfish curry canned, chemical characteristic, feasibility, microbiological characteristic

\section{PENDAHULUAN}

egara Indonesia kaya akan makanan tradisional yang sangat potensial untuk $\checkmark$ dikembangkan. Namun demikian, sebagian besar makanan tradisional memiliki masa simpan yang rendah. Salah satu upaya untuk meningkatkan masa simpan makanan tradisional adalah dengan teknologi proses pengalengan. Pengalengan adalah salah satu cara pengawetan bahan pangan dengan cara dikemas secara hermetis dan kemudian disterilkan. Pengemasan secara hermetis yaitu mengemas bahan pangan dalam suatu wadah baik kaleng, alumunium, atau gelas yang penutupannya sangat rapat, sehingga tidak dapat ditembus udara, air, kerusakan akibat oksidasi, maupun perubahan cita rasa.

Data statistik FAO (2014) melaporkan produksi ikan di dunia adalah sebesar 167,2 juta ton. Sebesar $87,5 \%$ digunakan untuk konsumsi, sedangkan $13 \%$ (19 juta ton) diolah melalui proses pengalengan. Proses pengalengan ikan terdiri dari tahapan meliputi persiapan bahan, proses blanching/precooking, pengisian bahan kedalam kaleng, penambahan media cairan (garam, minyak, atau saus), penghampaan udara/exhausting, penutupan kaleng, sterilisasi menggunakan retort, pendinginan, pengeringan, pelabelan, dan penyimpanan (Kumar, 2017).

Proses pengalengan terhadap produk berbasis ikan telah banyak dilakukan (Mohan et al., 2014; Markovic et al., 2015; Mohan et al., 2015; Zheng et al., 2016; Ali et al., 2017; Bahurmiz et al., 2018; Elshehawy dan Farag, 2019; Garcia et al., 2019; Mkadem dan Amar K., 2019). Menurut Caponio et al. (2011), jenis ikan yang biasa dikalengkan yaitu tuna, sarden, teri, dan makarel. Proses pengalengan ikan dapat dilakukan dengan menggunakan media larutan garam atau minyak. Herawati et al. (2016) melakukan proses pengalengan terhadap ikan patin dengan media larutan garam. Mesias et al. (2015) melakukan proses pengalengan ikan tuna dan ikan sarden dengan media larutan garam dan minyak. Selain menggunakan media garam atau minyak, media dengan larutan bumbu masakan tertentu juga dapat digunakan pada produk pengalengan. Maheswara et al. (2011) telah melakukan pengalengan ikan tuna dengan menggunakan media bumbu kari. Dalam penelitian ini, telah dilakukan proses pengalengan terhadap ikan lele dengan menggunakan media kuah/cairan bumbu mangut. Mangut lele merupakan makanan tradisional dari daerah "Mataraman" (Yogya-Solo) dan Semarang-Kendal. Sesuai dengan namanya, komposisi utamanya adalah lele goreng, yang diberi bumbu mangut. Penelitian ini bertujuan untuk melakukan analisis kelayakan usaha pengalengan mangut leledan melakukan karakteristik mangut lele yang dikemas dalam kemasan kaleng.

\section{BAHAN DAN METODE Bahan dan Alat}


Bahan yang dibutuhkan untuk proses pengalengan mangut lele adalah ikan lele dan bumbu mangut meliputi bawang merah, bawang putih, ketumbar, kemiri, cabai, daun salam, jahe, dan lengkuas. Alat yang digunakan untuk proses pengalengan antara lain seamer (VARIN), retort (TOMMY SS-325), dan bak pendingin.

\section{Metode}

Proses pengalengan mangut lele dimulai dengan pengisian mangut lele kedalam kaleng yang sudah disterilkan sebelumnya, dan ditimbang sebanyak 200 gram. Kemudian dilakukan penghampaan udara (exhausting) pada suhu $80^{\circ} \mathrm{C}$ selama 10 menit, selanjutnya dilakukan penutupan kaleng. Sterilisasi dilakukan pada suhu $121^{\circ} \mathrm{C}$ selama 20 menit menggunakan autoklaf. Tahapan sterilisasi merupakan tahapan penting dalam proses pengalengan. Kontrol terhadap suhu dan lama sterilisasi sangatlah penting untuk memastikan tidak adanya mikroorganisme yang tidak diharapkan, seperti Clostridium botulinum. Setelah sterilisasi selesai, dilanjutkan pendinginan pada produk kaleng di dalam bak pendingin untuk thermal shock terhadap mikroorganisme yang tidak diinginkan. Suhu yang diharapkan setelah proses pendinginan adalah $40-50^{\circ} \mathrm{C}$. Selanjutnya dilakukan karantina pada suhu $28-30^{\circ} \mathrm{C}$ selama 14 hari untuk memastikan produk pengalengan telah diproses dengan benar dan tepat.

Analisis kelayakan usaha dilakukan dengan menghitung teknoekonomi (Kurniadi, 2003) untuk usaha pengalengan mangut lele. Perhitungan teknoekonomi dilakukan dengan melakukan perhitungan biaya investasi (kebutuhan alat), biaya tetap (depresiasi alat dan tenaga kerja), dan biaya variabel (bahan, utilitas, pengemasan, bahan bakar dan production management). Keuntungan dapat dihitung dari selisih total pendapatan dan total biaya produksi. Perhitungan $\mathrm{B} / \mathrm{C}$ ratio dilakukan dengan menghitung pendapatan total dibagi dengan total biaya produksi.

Produk mangut lele kaleng yang diperoleh kemudian dilakukan pengujian karakteristik meliputi :

1. Pengujian thermal / kecukupan panas

2. Pengujian proksimat yaitu kadar air, kadar abu, protein, lemak mengacu pada AOAC (2005), karbohidrat by difference

3. Pengujian mikrobiologi meliputi angka lempeng total (ISO 4833:2003), coliformmenggunakan metode BAM (Peter et al. 2002), Salmonella (ISO, 2007), Staphylococcus aureus (BAM, 2001), Clostridium (BAM, 2001).

4. Pengujian cemaran logam meliputi timbal (AOAC 2005), tembaga, seng, timah, merkuri, arsen (BSN, 1998)

\section{HASIL DAN PEMBAHASAN}

Proses pengalengan telah dilakukan terhadap mangut lele. Spesifikasi kemasan kaleng yang digunakan yaitu ukuran $\varnothing 301 \times 205$ dengan ketebalan 0,5 mm, lapisan luar dari bahan Gold, dan lapisan dalam dari aluminium.

\section{Kelayakan Usaha Pengalengan Mangut Lele}

Untuk mengetahui potensi pengembangan usaha pengalengan mangut lele, dilakukan analisis kelayakan usaha dengan perhitungan teknoekonomi. Perhitungan ekonomi pengalengan mangut lele menggunakan beberapa asumsi, diantaranya :

1. Kapasitas produksi per bulan $=1000$ kaleng $/$ hari $\times 20$ hari kerja $=20000$ kaleng

2. Tenaga kerja yang diperlukan sebanyak 10 orang

3. Tahapan proses pengalengan menggunakan alat (mekanisasi produksi), kecuali pengisian dan penimbangan bahan dalam kaleng dilakukan manual

Perhitungan biaya tetap, biaya variabel, dan analisis ekonomi dapat dilihat pada Tabel 1 , 2, dan 3 . 
Tabel 1. Perhitungan Biaya Investasi Usaha Pengalengan Mangut Lele

\begin{tabular}{lrcr}
\hline \multicolumn{1}{c}{ Peralatan } & \multicolumn{1}{c}{$\begin{array}{c}\text { Harga } \\
(\mathrm{Rp})\end{array}$} & $\begin{array}{c}\text { Umur Pakai } \\
\text { (bulan) }\end{array}$ & $\begin{array}{c}\text { Depresiasi per } \\
\text { bulan (Rp) }\end{array}$ \\
\hline Seamers & $250,000,000$ & 60 & $4,166,666.67$ \\
Autoclave & $200,000,000$ & 60 & $3,333,333$ \\
Timbangan Digital & $2,400,000$ & 36 & 66,667 \\
Kompor LPG & $1,000,000$ & 36 & 27,778 \\
Alat Dapur & $4,000,000$ & 36 & 111,111 \\
Rak Karantina & $15,000,000$ & 60 & 250,000 \\
Lemari Pendingin & $2,000,000$ & 60 & 33,333 \\
Meja Proses & $3,000,000$ & 60 & 50,000 \\
Rak Penyimpanan Produk & $7,500,000$ & 60 & 125,000 \\
Bak Pendingin & $50,000,000$ & 60 & 833,333 \\
Exhausting box & $250,000,000$ & 60 & $4,166,667$ \\
Boiler & $250,000,000$ & 60 & $4,166,667$ \\
Total Biaya Investasi & $1,034,900,000$ & & $17,330,556$ \\
\hline
\end{tabular}

Seperti dapat dilihat pada Tabel 1 , total investasi yang dibutuhkan sebesar $1,034,900,000$ untuk pembelian mesin dan alat proses pengalengan. Perhitungan total biaya tetap diperoleh dengan menghitung biaya depresiasi alat dan biaya tenaga kerja seperti dapat dilihat pada Tabel 2.

Tabel 2. Perhitungan Biaya Tetap Usaha Pengalengan Mangut Lele

\begin{tabular}{lccc}
\hline \multicolumn{1}{c}{ Uraian } & Jumlah & Harga Satuan (Rp) & Harga Total (Rp) \\
\hline Depresiasi Alat & & & $17,330,556$ \\
Tenaga Kerja & 10 Orang & $2,000,000$ & $20,000,000$ \\
Total Biaya Tetap & & & $37,330,556$ \\
\hline
\end{tabular}

Perhitungan biaya variabel meliputi biaya bahan baku dan bahan pendukung, biaya listrik, bahan bakar seperti dapat dilihat pada Tabel 3.

Tabel 3. Perhitungan Biaya Variabel Usaha Pengalengan Mangut Lele

\begin{tabular}{lrrrr}
\hline \multicolumn{1}{c}{ Uraian } & Jumlah & Satuan & $\begin{array}{r}\text { Harga Satuan } \\
\text { (Rp) }\end{array}$ & $\begin{array}{c}\text { Harga Total } \\
\text { (Rp) }\end{array}$ \\
\hline Ikan lele & & & 23,000 & $75,900,000$ \\
Bumbu & 3,300 & $\mathrm{~kg}$ & 2,000 & $40,000,000$ \\
Utilitas (listrik,air) & 20,000 & paket & $2,000,000$ & $2,000,000$ \\
LPG & 1 & bulan & 2,000 & 800,000 \\
Solar & 8 & unit & 100,000 & $9,750,000$ \\
Pengemasan (kaleng, label, dus) & 1500 & liter & 6,500 & $7,000,000$ \\
Production management & 20000 & kaleng & 3,500 & 70,000 \\
Total Biaya Variabel & 1 & bulan & $2,500,000$ & $2,500,000$ \\
\hline
\end{tabular}

Setelah menentukan biaya tetap dan biaya variabel, dilakukan perhitungan teknoekonomi seperti dapat dilihat pada Tabel 4.

Tabel 4. Perhitungan Teknoekonomi Usaha Pengalengan Mangut Lele

\begin{tabular}{lccr}
\hline & Uraian & Satuan & Nilai \\
\hline Kapasitas Produksi & kaleng/bulan & 20,000
\end{tabular}


Biaya produksi total (biaya tetap dan biaya variable)

Cost of good sold (CoGS) (Biaya produksi total : kapasitas produksi)

Keuntungan $20 \%$ (dari nilai CoGS)

Biaya pemasaran 5\% (dari nilai CoGS)

Biaya transportasi $5 \%$ (dari nilai CoGS)

Pajak (PPH\&PPN $=12.5 \%)($ dari nilai CoGS $)$

Harga jual

Pendapatan total jika $100 \%$ terjual

Keuntungan sebelum pajak (pendapatan total -

biaya produksi total)

$\mathrm{B} / \mathrm{C}$ ratio (pendapatan total : biaya produksi total)

Rp/bulan

Rp/kaleng

Rp/kaleng

Rp/kaleng

Rp/kaleng

Rp/kaleng

Rp/kaleng

Rp/bulan

Rp/bulan

$\begin{array}{cc}- & 1.43 \\ \% & 42.50\end{array}$

$238,280,556$

11,914

$2,382.81$

596

596

1,489

16,977

$339,549,792$

$101,269,236$

Menurut Sutoyo (2000) dalam Kurniadi (2003), nisbah B/C ratio dan IRR dapat digunakan untuk mengetahui layak tidaknya suatu kegiatan usaha untuk dikembangkan. Jika $\mathrm{B} / \mathrm{C}$ ratio $>1$ maka usaha dinyatakan layak, jika $\mathrm{B} / \mathrm{C}$ ratio $<1$ kegiatan usaha tidak layak untuk dikembangkan. Dari hasil perhitungan teknoekonomi, seperti dapat dilihat pada Tabel $8, \mathrm{~B} / \mathrm{C}$ ratio usaha pengalengan mangut lele $>1$ sehingga usaha pengalengan ini sangat potensial untuk dikembangkan bahkan cukup menguntungkan.

\section{Karakteristik Termal / Kecukupan Panas}

Bila suatu makanan di kemas dalam kaleng dan diletakkan dalam retort, suhu produk tidak segera mencapai suhu proses, tetapi panas akan merambat secara perlahan. Kecepatan penetrasi panas dari retort ke dalam produk dapat diketahui dengan heat penetration test (Nurhikmat et al., 2016). Pengujiannya dilakukan dengan meletakkan ujung termokopel pada bagian terdingin.

Resistensi panas mikroorganisme dinyatakan sebagai waktu kematian termal atau Thermal Death Time (TDT) yaitu waktu yang dibutuhkan untuk membunuh sejumlah sel atau spora tertentu pada kondisi fisik tertentu (temperatur, jumlah dan tipe mikroorganisme, serta karakteristik medium pemanas). TDT pada temperatur $121^{\circ} \mathrm{C}$ telah digunakan sebagai referensi sterilitas dan dinyatakan sebagai Fo. Untuk pengalengan ikan, nilai Fo minimal yang dipersyaratkan adalah 2,52 menit pada suhu $121,1^{\circ} \mathrm{C}$ untuk mengurangi dan menginaktifkan spora Clostridium botulinum (Kumar, 2017).

Untuk mengetahui TDT atau Fo dipergunakan persamaan yang disampaikan Richardson (2001),

$$
\log L=\frac{T-121}{10}
$$

atau

$$
L=10^{\{(T-121 / 10)\}}
$$

dimana Fo yang merupakan penjumlahan dari kematian bakteri selama periode waktu pemanasan dapat dihitung dengan persamaan :

$$
F_{O}=\int L d t
$$

Telah dilakukan pengujian kecukupan panas pada mangut lele kaleng menggunakan alat Fo meter (ELLAB CTF9004). Data observasi yang diperoleh selanjutnya dihitung dan dimasukkan ke dalam persamaan sehingga diperoleh nilai Fo seperti dapat dilihat pada Gambar 1. 


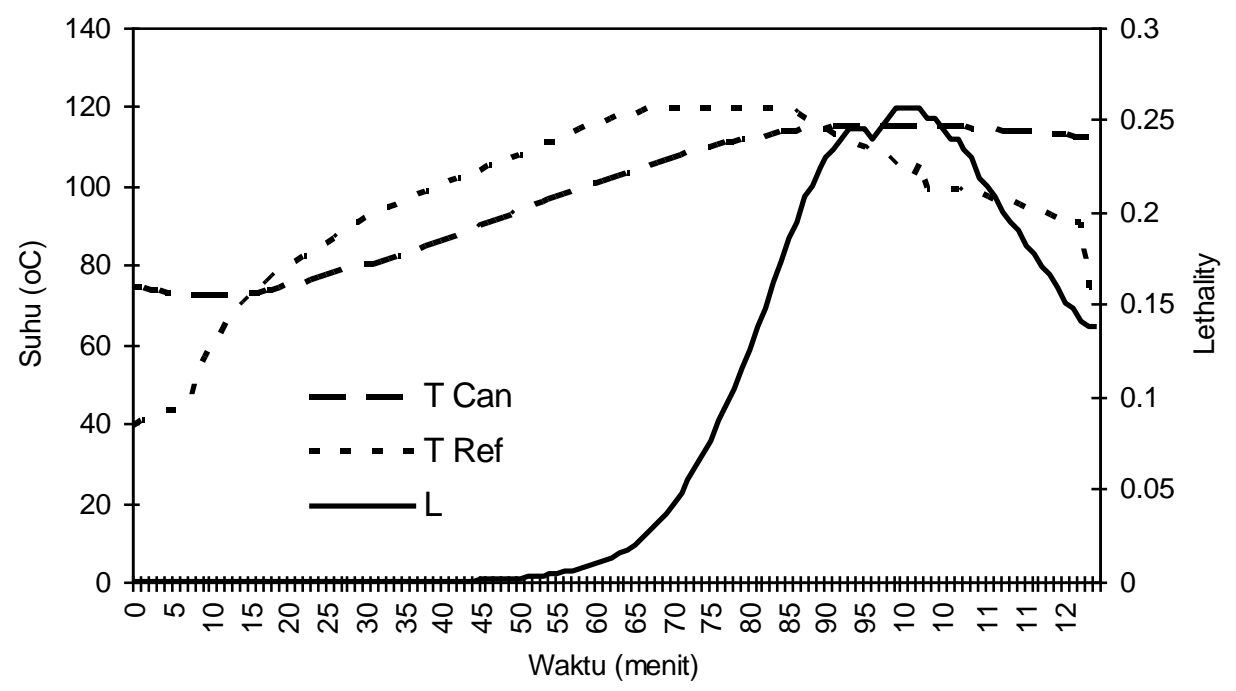

Gambar 1. Nilai Fo mangut lele dalam kemasan kaleng adalah 10,48 menit

Hasil perhitungan menunjukkan bahwa nilai Fo mangut lele adalah sebesar 10,48 menit. Berdasarkan FDA (2005) yang menyebutkan bahwa sterilisasi standar dilakukan pada suhu $121^{\circ} \mathrm{C}$ dengan nilai penghancuran spora Clostridium botulinum sebesar 3 menit (Fo 3 atau botulinum cook), maka produk mangut lele kaleng telah aman karena memiliki nilai Fo sebesar 10,48 menit. Maheswara et al. (2011) juga melaporkan nilai Fo pada ikan tuna kaleng dengan media bumbu kari adalah sebesar 10,13 menit. Hasil penelitian Chandra et al.(2014) melaporkan nilai Fo pada ikan layur dengan media bumbu kari adalah sebesar 10,8 menit.

\section{Karakteristik Kimia dan Perhitungan Nilai Kalori}

Telah dilakukan pengujian karakteristik kimia/proksimat produk mangut lele kaleng, meliputi kadar air, kadar abu, kadar protein, kadar lemak, dan kandungan karbohidrat seperti dapat dilihat pada Tabel 5.

Tabel 5. Pengujian Proksimat Mangut Lele Kaleng

\begin{tabular}{ccc}
\hline Komposisi & \% Berat basah & \% Berat kering \\
\hline kadar air & $75.71 \pm 0.11$ & - \\
kadar abu & $2.30 \pm 0.04$ & $9.47 \pm 0.14$ \\
lemak & $6.24 \pm 0.06$ & $25.69 \pm 0.37$ \\
protein & $12.30 \pm 0.07$ & $50.64 \pm 0.42$ \\
karbohidrat & $3.45 \pm 0.05$ & $14.20 \pm 0.21$ \\
\hline
\end{tabular}

Ikan mengandung berbagai komposisi gizi, meliputi kadar air, protein, lemak, mineral, kalsium, fosfor, dan vitamin A,D, B, C. Ikan telah banyak digunakan sebagai salah satu sumber protein hewani dan nutrisi lain untuk kesehatan manusia di seluruh dunia (Farid et al., 2014; Hantoush et al., 2014; Reza et al., 2015).

Hasil pengujian proksimat menunjukkan bahwa kandungan protein produk mangut lele cukup tinggi, yaitu sebesar $12,30 \%$ wb. Banyak penelitian melaporkan tingginya kandungan protein pada ikan lele (Swastawati et al., 2013; Yuarni et al., 2015; Justisia dan Adi, 2016; Sulfiani et al., 2017; Abraha et al., 2018). Ikan lele mengandung asam amino lisin dan leusin yang berfungsi untuk pertumbuhan anak-anak, perbaikan jaringan, menghasilkan antibodi, dan membantu penyerapan kalsium (Murniyati et al., 2013).

Herawati et al. (2016) juga melaporkan kandungan protein yang tinggi yaitu 14,33\% wb pada ikan patin kaleng. Produk ikan dalam kemasan kaleng lainnya, yaitu ikan chela 
(Laubuka dadiburjorı) dilaporkan memiliki kandungan protein tinggi, yaitu $16,68 \%$ dengan pengalengan menggunakan larutan garam (Al-Reza et al., 2015). Kandungan lemak pada mangut lele kaleng adalah $6,24 \%$ wb. Karl et al.(2014) menyebutkan kandungan lemak produk ikan kaleng komersial di negara Turki berkisar antara 6,7 - 24,3\%. Konsumsi beberapa jenis ikan yang mengandung lemak tinggi dapat meningkatkan asupan asam lemak omega-3 dan mencegah penyakit jantung koroner (Morales et al., 2015; Yetunde, 2016).

Dari pengujian proksimat yang telah dilakukan, dapat dihitung dan ditentukan nilai kalori produk mangut lele kaleng seperti dapat dilihat pada Gambar 2.

\begin{tabular}{|l|l|} 
Makaran Saji & $: 100 \mathrm{~g}$ \\
Energi Total & $: 119 \mathrm{kkal}$ \\
Energi dari lemak & $: 56 \mathrm{kkal}$ \\
\%AKG berdasarkan kebutuhan energi $2000 \mathrm{kkal}$ & \\
Lemak total $: 16 \%$ \\
Protein $\quad: 16 \%$ \\
Karbohidrat $: 1 \%$
\end{tabular}

Gambar 2. Perhitungan Kalori Mangut Lele Kaleng

Produk mangut lele kaleng dengan takaran saji 100 gram mengandung energi total sebesar 119 kkal. Nilai kalori mangut lele kaleng ini lebih rendah daripada nilai kalori ikan tongkol kaleng sebesar 276 kkal (Aberoumand, 2012) dan pada ikan tuna kaleng sebesar 393 kkal (Aberoumand dan Fazeli, 2019), karena perbedaan kandungan lemak. Ikan tongkol kaleng mengandung lemak sebesar $15,2 \%$ dan ikan tuna kaleng mengandung lemak sebesar $36,27 \%$, jauh lebih tinggi dibandingkan kandungan lemak pada mangut lele kaleng.

\section{Karakteristik Mikrobiologi}

Karakteristik mikrobiologi produk mangut lele kaleng dapat dilihat pada Tabel 6.

Tabel 6. Karakteristik Mikrobiologi Mangut Lele Kaleng

\begin{tabular}{lcc}
\hline \multicolumn{1}{c}{ Analisis } & Jumlah & Satuan \\
\hline Angka lempeng total $30^{\circ} \mathrm{C} 72$ jam & & - \\
(ALT) & $<10$ & \\
Coliform & $<3$ & APM/gram \\
Salmonella sp & negatif & $/ 25 \mathrm{gram}$ \\
Staphylococcus aureus & negatif & $/ \mathrm{gram}$ \\
Clostridium perfringens & negatif & /gram \\
\hline
\end{tabular}

Hasil pengujian menunjukkan bahwa produk mangut lele aman untuk dikonsumsi karena produk negatif tidak mengandung bakteri yang patogen, yaitu negatif dari Salmonella $s p$, negatif dari Staphylococcus aureus, dan negatif dari Clostridium perfringens. Hasil pengujian sesuai dengan Peraturan Kepala BPOM RI (2009) tentang Penetapan Batas Maksimum Cemaran Mikroba dan Kimia Dalam Makanan, yang menyebutkan bahwa syarat cemaran mikrobia produk perikanan yang dikalengkan adalah jumlah angka lempeng total $<1 \times 10^{1} \mathrm{koloni} / \mathrm{g}$ dan negatif dari Clotridium.

\section{Karakteristik Cemaran Logam}


Telah dilakukan analisa cemaran logam pada produk mangut lele kaleng seperti dapat dilihat pada Tabel 7.

Tabel 7. Karakteristik Cemaran Logam Mangut Lele Kaleng

\begin{tabular}{lc}
\hline Analisis & Jumlah $(\mathrm{mg} / \mathrm{kg})$ \\
\hline Timbal $(\mathrm{Pb})$ & $<0.0007$ \\
tembaga $(\mathrm{Cu})$ & 0.0718 \\
seng $(\mathrm{Zn})$ & 0.0022 \\
Timah $(\mathrm{Sn})$ & $<0.8$ \\
mercuri $(\mathrm{Hg})$ & $<0.0003$ \\
Arsen $(\mathrm{As})$ & 0.029 \\
\hline
\end{tabular}

Peraturan Kepala BPOM (2009) tentang Penetapan Batas Maksimum Cemaran Mikroba dan Kimia Dalam Makanan, menyebutkan bahwa syarat cemaran logam produk perikanan yang dikalengkan adalah batas maksimum kandungan timah (Sn) sebesar 250 $\mathrm{mg} / \mathrm{kg}$. Sedangkan untuk cemaran logam lainnya, di Peraturan Kepala BPOM (2009) kategori pangan lainnya, batas maksimum cemaran timbal $(\mathrm{Pb})$ sebesar $0,25 \mathrm{mg} / \mathrm{kg}$, arsen (As) 0,25 $\mathrm{mg} / \mathrm{kg}$, mercuri $(\mathrm{Hg})$ 0,03. Dari Tabel 7, dapat dilihat bahwa hasil pengujian cemaran logam masih jauh lebih rendah dari batas maksimum yang diijinkan.

Proses pengalengan menjadi salah satu alternatif teknologi proses yang sangat potensial untuk dikembangkan pada makanan tradisional Indonesia terutama untuk meningkatkan masa simpan produk. Al-Reza et al. (2015) melaporkan hasil pengujian sensoris dan karakteristik fisik terbaik pada ikan chela adalah ketika diproses dengan teknologi pengalengan atau dengan dibekukan, dibandingkan dengan metode pengeringan atau pengasapan.

\section{KESIMPULAN}

Analisa teknoekonomi telah dilakukan terhadap pengalengan mangut lele dengan kapasitas produksi sebesar 1000 kaleng/hari. Nilai Return of Investment (ROI) cukup tinggi, sehingga usaha produksi pengalengan mangut lele ini sangat layak untuk dikembangkan. Nilai Fo/kecukupan panas proses pengalengan mangut lele sebesar 10,48 menit. Karakteristik kimia mangut lele kaleng meliputi kadar air 75,71\%; kadar abu 2,30\%; lemak 6,24\%; protein 12,30\%; dan karbohidrat 3,45\%. Mangut lele kaleng mengandung 119 kalori per 100 gram produk. Pengujian mikrobiologi menunjukkan produk negatif dari kandungan salmonella, staphylococcus aureus, dan clostridium. Pengujian cemaran logam telah dilakukan dan hasilnya masih batas aman yaitu timbal $(\mathrm{Pb})<0,0007 \mathrm{mg} / \mathrm{kg}$; tembaga $(\mathrm{Cu})$ $0,0718 \mathrm{mg} / \mathrm{kg}$; seng (Zn) 0,0022 mg/kg; timah (Sn) <0,8 mg/kg; mercuri $(\mathrm{Hg})<0,0003$ $\mathrm{mg} / \mathrm{kg}$; arsen (As) 0,029 mg/kg.

\section{DAFTAR PUSTAKA}

Aberoumand, A. 2012. Proximate composition of less known some processed and fresh fish species for determination of the nutritive values in Iran. Journal of Agricultural Technology 8(3): 917-922.

Aberoumand, A. dan A. Fazeli. 2019. Comparison of analysis and the nutritional value of fresh common carp, frozen and southern canned tuna. Potravinarstvo Slovak Journal of Food Sciences13(1): 593-597.

Abraha, B., H. Admassu, dan A. Mahmud. 2018. Effect of processing methods on nutritional and physico-chemical composition of fish: a review. MOJ Food Process Technol 6(4): 376-382. 
Ali, H., E.H. Mansour, dan A.E.A. El-Bedawey. 2017. Quality of canned tilapia fish luncheon as influenced by different concentrations of beef fat and storage time. Food Measure11: 1240-1247.

Al-Reza, S., S. Karmaker, M. Hasan, S. Roy, R. Hoque, dan N. Rahman. 2015. Effect of Traditional Fish Processing Methods on the Proximate andMicrobiological Characteristics of Laubuka dadiburjori DuringStorage at Room Temperature. Journal of Fisheries and Aquatic Science 10(4) : 232-243.

AOAC, 2005. Official Methods of Analysis. 18th (Ed)., Association of Official Analytical Chemists, Washington, DC., USA.

Badan Standardisasi Nasional, 1998. SNI 01- 4866-1998: Cara uji Cemaran Arsen dalam Makanan.

Bacteriological analytical manual BAM. 2001. Staphylococcus aureus: US.FDA.http://www.fda.gov/Food/FoodScienceResearch/LaboratoryMethods/ucm07142 9.htm

Bahurmiz, O.M., M. Al-Sa'ady, dan F. Adzitey. 2018. Nutritional and sensory characteristics of locally produced canned tuna from Hadhramout, Yemen. International Journal of Food Science and Nutrition 3(5): 13-18.

Caponio, F., C. Summo, A. Pasqualone, dan T. Gomes. 2011. Fatty acid composition and degradation level of the oils used in canned fish as a function of the different types of fish. J. Food Compos. Anal. 24: 1117-1122.

Chandra, M.V., C.V. Raju, dan V.K. Reddy. 2014. Influence of Heat Penetration on the Quality of Canned Ribbon Fish (Trichiurus lepturus). Journal of Food Processing and Preservation38(3): 807-814.

Elshehawy, S., Z. dan S. Faraq. 2019. Safety assessment of some imported canned fish using chemical, microbiological and sensory methods. Egyptian Journal of Aquatic Research 45: 389-394.

Farid, F.B, G.A. Latifa, dan M.N. Nahid. 2014. Effect of Sun-drying on proximate composition and $\mathrm{pH}$ of Shoal fish treated with Salt and Salt-turmeric storage at Room Temperature $\left(27^{\circ} \mathrm{C}-30^{\circ} \mathrm{C}\right)$. IOSR Journal of Agriculture and Veterinary Science (IOSR-JAVS) 7(9): 18.

FAO, 2014. Food and Agriculture Organization of the United Nations, Fisheries Department Statistical Databases and software, Yearbooks of Fishery Statistics Summary tables. http://www.fao.org

Food and Drug Administration (FDA). 2005. Food and Drugs, Chapter 1-Food and Drug Administration Departement of Health and Human Services, Subchapter B-Food for Human Consumption, Code of Federal Regulations, Title 21, Volume Revised as of April $1,2005$.

Garcia, T., C. Cardoso, C. Afonso, A. Gomes, C. Mesquita, S. Tanni, dan N. M. Bandarra. 2019. A Study of Lipid Bioaccessibility in Canned Sardine (Sardina pilchardus) and Chub Mackerel (Scomber japonicus). Journal of Aquatic Food Product Technology 28(4): 402-412.

Hantoush, A. A., Q.H. Al-hamadany, dan A.S. Al-Hassoon. 2014. Nutritional value of important commercial fish from Iraqi waters. Mesopot J Mar Sci. 29(1): 13-22.

Herawati, E.R.N., M. Angwar, A. Susanto, dan M. Kurniadi. 2016. Effect of Brine Concentration on the Nutrient Content and Fatty Acid Profile of Canned Catfish [Pangasius sutchi (Fowler, 1937)] Aquatic Procedia 7:85 - 91.

ISO 4833:2003. Microbiology of food and animal feeding stuffs - Horizontal method for the enumeration of microorganisms - Colony-count technique at 30 degrees C.American National Standards Institute (ANSI). 
International Organization for Standardization 2007. ISO 6579:2002/Amd 1:2007 Detection of Salmonella spp. in animal faeces and in environmental samples from the primary production stage, amendment 1, annex D. In Microbiology of food and animal feeding stuffs. Horizontal method for the detection of Salmonella spp. International Organization for Standardization, Geneva, Switzerland.

Jie, Z., R. Yuan-yuan, G. Jian-zhong, Y. Lu-lu, Y. Si-yu, L. Yao-shang, J. Xu, dan H. Ai-jun. 2016. Analysis of Nutrients in Fresh and Canned Pseudobagrus. Journal of Food and Nutrition Research 4(7): 417-421.

Justisia, S.R.W., dan A.C. Adi. 2016. Peningkatan Daya Terima dan Kadar Protein Nugget Substitusi Ikan Lele (Clarias Batrachus) dan Kacang Merah (Vigna Angularis). Media Gizi Indonesia 11(1): 106-112.

Karl, M., U. Ostermeyer, C. Altınelataman, U. Çelik, dan J. Oehlenschlager. 2014. Chemical Composition, Cholesterol, Trace Metals and Amino Acid Composition of Different Canned Fish Products Produced and Sold in Turkey. Journal of Fisheries Sciences.com8(1): 17-26.

Kumar, A. 2017. Recent trends in harvest and post-harvest technologies in fisheries. Central Institute of Fisheries Technology, Kochi, India.

Kurniadi, M. 2003. Kajian Pengembangan Beberapa Industri Pengolahan Hasil Perikanan Laut di Kabupaten Lampung Timur. Tesis. Program S2 Teknologi Agroindustri Universitas Lampung. Bandar Lampung.

Markovic, G., J. Mladenovic, M. Cvijovic, dan J. Miljkovic. 2015. Total protein and lipid contents of canned fish on the Serbian market. Acta Agriculturae Serbica 20(39): 6774.

Mkadem, H., dan A. Kaanane. 2019. Recovery and Characterization of Fish Oil from Byproducts of Sardine (Sardina pilchardus) in the Canning Process. Journal of Aquatic Food Product Technology28(10): 1037-1050.

Mohan, C. O., S. Remya, C. N. Ravishankar, P. K. Vijayan, dan T. K. Srinivasa Gopal. 2014. Effect of filling ingredient on the quality of canned yellowfin tuna (Thunnus albacares). International Journal of Food Science and Technology 49(6): 1557-1564.

Mohan, C. O., S. Remya, L. N. Murthy, C.N. Ravishankar, dan K. Asok Kumar. 2015. Effect of filling medium on cooking time and quality of canned yellowfin tuna (Thunnus albacares). Food Control 50:320-327.

Morales M., F. Holgado, dan R. Sevenich. 2015. Fatty acids profile in canned tuna and sardine after retort sterilization and high pressure thermal sterilization treatment. Journal of Food and Nutrition Research54(2): 171-178.

Murniyati. T. Suryaningrum, dan I. Muljanah. 2013. Membuat Filet Lele dan Produk Olahannya.Penebar Swadaya, Jakarta.

Nurhikmat,A., B. Suratmo, N. Bintoro, dan Suharwadji. 2016. Pengaruh Suhu dan Waktu Sterilisasi terhadap Nilai $\mathrm{F}$ dan Kondisi Fisik Kaleng Kemasan pada Pengalengan Gudeg. Agritech 36(1): 71-78.

Peter, F., D. Stephen, A. Michael, dan B. William. 2002. Bacteriological Analytical Manual (BAM) 4 : Enumeration of Eschericia coli and the Coliform Bacteria.

Maheswara, K., C.V. Raju, J. Naik, R.M. Prabhu, dan K. Panda. 2011. Studies on Thermal Processing of Tuna - A Comparative Study in Tin and Tin-Free Steel Cans. African Journal of Food, Agriculture, Nutrition and Development 11(7): 5539-5560.

Mesias, M., F. Holgado, R. Sevenich, J.C. Briand, R. Marquez, Gloria, dan F.J. Morales. 2015. Fatty acids profile in canned tuna and sardine after retort sterilization and high pressure thermal sterilization treatment. Journal of Food and Nutrition Research54: 171-178.

Reza, S. A., S. Karmaker, dan M. Hasan. 2015. Effect of Traditional Fish Processing Methods on the Proximate and Microbiological Characteristics of Laubuka dadiburjori During 
Storage at Room Temperature. Journal of Fisheries and Aquatic Science 10(4): 232243.

Sulfiani, A., A. Sukainah, dan A. Mustarin. 2017. Pengaruh Lama dan Suhu Pengasapan dengan Menggunakan Metode Pengasapan Panas terhadap Mutu Ikan Lele Asap. Jurnal Pendidikan Teknologi Pertanian 3: S93-S101.

Swastawati, F., T. Surti, T. Winarni Agustini, dan P. Hariyadi. 2013. Karakteristik Kualitas Ikan Asap Yang di Proses Menggunakan Metode dan Jenis Ikan Berbeda. Jurnal Aplikasi Teknologi Pangan 2(3): 126-132.

Yetunde, K. O. 2016. Biochemical composition of Micromesistus poutassou from agbalata market, Badagry Lagos West, Nigeria. Food and Applied Bioscience Journal 4(1): 1214.

Yuarni, D., K. Kardiman, dan J. Jamaluddin. 2015. Laju Perubahan Kadar Air, Kadar Protein, dan Uji Organoleptik Ikan Lele Asin Menggunakan Alat Pengering Kabinet (Cabinet Dryer) dengan Suhu Terkontrol. Jurnal Pendidikan Teknologi Pertanian 1: 12-21. 